\title{
Influence of shellfish farming activities on nitrification, nitrate reduction to ammonium and denitrification at the water-sediment interface of the Thau lagoon, France
}

\author{
Franck Gilbert ${ }^{1}$, Philippe Souchu ${ }^{2}$, Micheline Bianchi ${ }^{3}$, Patricia Bonin ${ }^{1, *}$ \\ ${ }^{1}$ Laboratoire d'Océanographie et de Biogéochimie, Centre d'Océanologie de Marseille (OSU), Université de la \\ Méditerranée, CNRS UMR 6535, Campus de Luminy, Case 901, F-13288 Marseille Cedex 9, France \\ ${ }^{2}$ Laboratoire d'Ecologie, station IFREMER, 1 rue Jean Vilar, F-34200 Sète, France \\ ${ }^{3}$ Laboratoire de Microbiologie Marine, CNRS UPR 223, Campus de Luminy, Case 907, F-13288 Marseille Cedex 9 , France
}

\begin{abstract}
The seasonal patterns of nitrification, denitrification and dissimilatory ammonium production (DAP) rates were studied in the sediment of 2 stations in the Thau lagoon (south of France). The station ZA was located within the shellfish farming zone and the station B was the reference site. A marked effect of shellfish farming on bacterial activities was observed. Spatial differences were associated with discrepancies in the organic content and the reduction state of sediments, i.e. highest reductive processes (dentrification and DAP) were noted in shellfish farming area, whereas the oxidative process (nitrification) was predominant outside the farming zone. At both stations, the DAP activity increased in September (autumn) concomitant with an increase of the $\mathrm{C} / \mathrm{N}$ ratio in the sediment due to the sedimentation of the summer phytoplanktonic production. Nitrification and denitrification rates exhibited maxima in November (winter) corresponding to dissolved inorganic nitrogen inputs from the surrounding land. In the shellfish farming site, $98 \%$ of nitrate was reduced to $\mathrm{NH}_{4}^{+}$and $2 \%$ to $\mathrm{N}_{2} \mathrm{O}$, showing that the most of the $\mathrm{NO}_{3}{ }^{-}$was reduced to ammonium and remained available for the ecosystem.
\end{abstract}

KEY WORDS: Shellfish farming - Nitrogen bacterial processes - Nitrification - Nitrate reduction to ammonium - Denitrification - Thau lagoon - Mediterranean Sea Sediment-water exchanges

\section{INTRODUCTION}

The potential importance of nutrients in influencing the productivity of marine ecosystems is now well recognised, especially that of dissolved inorganic nitrogen, which appears to limit the primary production in coastal ecosystems (Ryther \& Dunstan 1971). Benthic remineralisation is an important pathway in shallow ecosystems (Zeitzschel 1980, Nixon 1981), and the recycled $N$ released from sediments can substantially contribute to the nitrogen requirement for phytoplankton growth (Nixon 1981).

- Addressee for correspondence.

E-mail:pbonin@com.univ-mrs.fr
Three major bacterial processes in sediments affect the nitrogen cycle, playing important roles in nitrogen budgets and fluxes of the ecosystem: (1) the ammonium oxidation by nitrification in sediments not only competes with heterotrophic processes for limited supplies of oxygen and nitrogen, but can also indirectly remove nitrogen through its coupling with the denitrification process (Koike \& Hattori 1978, Jenkins \& Kemp 1984). (2) During the remineralisation of organic nitrogen in sediments, 15 to $70 \%$ of $\mathrm{N}$ can be lost by denitrification (Seitzinger 1988). Furthermore, benthic denitrification can also decrease nitrate influxes from terrestrial origin (Jørgensen \& Sørensen 1985, Jørgensen \& Sørensen 1988). (3) Dissimilatory nitrate reduction to ammonium, referred to as dissimilatory 
ammonium production (DAP), competes for nitrate with denitrification in sediments (Serensen 1978a, Enoksson \& Samuelsson 1987). The relative contribution of denitrification and DAP to nitrate reduction is of considerable importance, as the former acts as a nitrogen sink for the ecosystem whilst the latter maintains the nitrogen levels.

The Thau lagoon (south of France) is the biggest shellfish breeding area in Europe with an estimated standing stock of 40000 t of oysters (Crassostrea gigas and their epibiota) at a density of about 40 oysters $\mathrm{m}^{-2}$ of shellfish farming zone $e_{i}$ the harvesting of oysters leads to the removal of large quantities of nitrogen from the ecosystem. Thus, the knowledge of the shellfish farming effect on bacterial activities associated with the $\mathrm{N}$ cycle is necessary for a better understanding of the $N$ cycle. Kaspar et al. (1985) showed that the denitrification rate was 7 times higher in sediments from a mussel farm compared to from a reference site. Nevertheless, other experiments have shown that high loading of organic matter to sediments tends to decrease $N$ removal by diminishing the coupling of nitrification and denitrification (Jenkins \& Kemp 1984 Blackburn et al. 1988, Sloth et al. 1995, Jensen et al. 1996). This paper reports the first results on nitrification, DAP and denitrification measurements at the sediment-water interface of the shellfish farm and at a reference site in the Thau lagoon.

\section{MATERIALS AND METHODS}

Studied sites. The study was carried out in the Thau lagoon, a shallow lagoon of $75 \mathrm{~km}^{2}$ located on the French Mediterranean coast (Fig. 1). This lagoon is connected to the sea through the narrow channels of Sète and receives freshwater mostly from the north shore. The Vène and Pallas are the major rivers representing $43 \%$ of the total watershed $\left(280 \mathrm{~km}^{2}\right)$. Two stations were chosen for their differences due to sediment alteration induced by biodeposition (Mesnage \& Picot 1995. Mazouni et al. 1996). Stn ZA (8.5 m depth), located inside the eastern shellfish farming zone, has been previously described in Souchu et al. (1997). Stn $\mathrm{B}$ (8.5 $\mathrm{m}$ depth), which is the reference site, shows a particle size similar to that of Stn ZA, with the fraction below $63 \mu \mathrm{m}$ constituting between 80 and $90 \%$. The macrophytobenthos is almost totally absent at these relatively deep stations (Gerbal \& Verlaque 1995), and a description of benthic macrofauna and meiofauna can be found in Guelorget et al. (1994). The stations were studied 4 times between June 1994 and April 1995, i.e. June, September and November 1994 and April 1995. Sediments from Stn ZA consisted of black mud giving off a hydrogen sulphide smell $\left(\mathrm{H}_{2} \mathrm{~S}\right)$. The

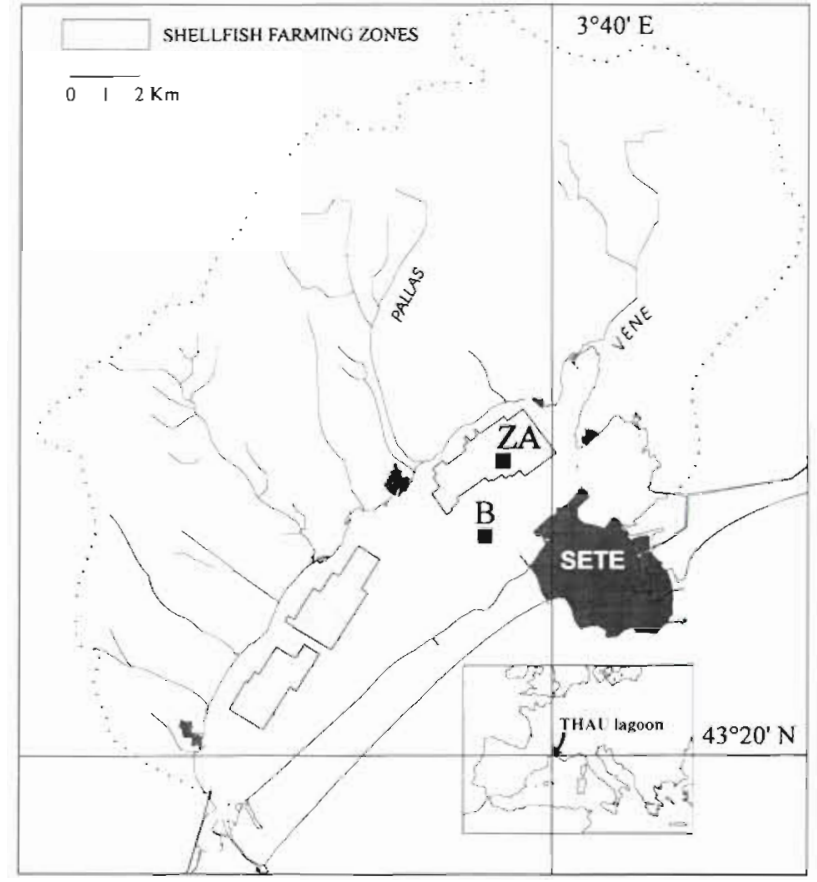

Fig. 1. Location of the study sites inside ( $\operatorname{Stn} Z A$ ) and outside (Stn B) the shell farming zone

interface was partly covered by filamentous cyanobacteria. Sediments from Stn B were made of a grey mud, lightly ( 1 or 2 ind. $\mathrm{m}^{-2}$ ) colonised by the worm Sabella pavonina (Savigny). In September and November, the absence of macrofauna and the blackening of sediments at Stns ZA and B indicated that both stations suffered from bottom anoxia in August. In September, sediments from both stations were covered by a yellow-brown layer rich in suspended particles.

Water column. Bottom water $(0.5 \mathrm{~m}$ above the bottom) was sampled with a Niskin bottle. Filtration and storage of samples were performed within $1 \mathrm{~h}$ after sampling Samples for ammonium $\left(\mathrm{NH}_{4}{ }^{+}\right)$determination were fixed immediately and measured by the colorimetric method of Koroleff (1976) using Bertelot's reaction. Samples were filtered (Whatman GF/F filter) and stored for later determination of $\mathrm{NO}_{2}^{-}$and $\mathrm{NO}_{3}{ }^{-}$concentrations with a segmented flow analyser (Tréguer \& Le Corre 1975). A detailed procedure of sampling, filtration and storage is described in Souchu et al. (1997). Records of daily rainfall at Sète were obtained from the National Meteorological Board of Montpellier. Salinity and temperature, recorded using a WTW LF 196 conductimeter laccuracy $\pm 0.5 \%$, were provided by the observation network of IFREMER.

Sediments. Dry organic matter content and oxygen and redox profiles were measured in sediments collected in acrylic tubes by divers. At Stn ZA, sediments 
were sampled $3 \mathrm{~m}$ outside the suspended lines of a shellfish farm

For the percentages of dry organic matter (\%OM), triplicate $8 \mathrm{~cm}$ wide cores were sliced into $1 \mathrm{~cm} \mathrm{sec-}$ tions, from which known volumes of sediment were freeze-dried and then heated at $450^{\circ} \mathrm{C}$ for $12 \mathrm{~h}$

For the pore water sediment extraction, triplicate $8 \mathrm{~cm}$ wide cores were cut into $1 \mathrm{~cm}$ segments inside a nitrogen-filled glove bag to avoid air oxidation of reduced nitrogen compounds dissolved in the water Each slice of sediment was centrifuged at $10000 \mathrm{rpm}$ $(8620 \times g)$ for $15 \mathrm{~min}$ with a refrigerated centrifuge (Heraeus Megafuge 20R). Supernatant water was removed from the centrifuge tube, filtered through Whatman GF/F filters and frozen in precombusted Pyrex flasks for later determination of $\mathrm{NH}_{4}{ }^{+}, \mathrm{NO}_{2}{ }^{-}$and $\mathrm{NO}_{3}{ }^{-}$concentrations as described for the water column. Interference of sulphides with Berthelot $\left(\mathrm{NH}_{4}{ }^{+}\right)$ colorimetric reactions was avoided by a dilution $(\times 100)$ with deionized water

Redox potential and oxygen concentration were measured immediately after arrival in the laboratory with a $\mathrm{pH} / \mathrm{mV}$ (Schott CG817T) meter equipped with combined platinum mini-electrodes and a $\mathrm{Ag} / \mathrm{AgCl}$ reference electrode. Before each measurement, a delay of 2 min allowed the reading to become constant. The oxygen concentration in the sediment was measured with a mini-electrode with a tip diameter of $0.5 \mathrm{~mm}$ (Visscher et al. 1991) and an Ag/ AgCl external reference electrode. The electrodes were connected to a picoammeter (Keithley 485), with a $750 \mathrm{mV}$ polarisation charge positive to the reference electrode. Calibration under non-stirred conditions revealed a linear relationship between oxygen concentration and the observed signal. Typical 0 and $100 \%$ air saturation values were 1 and $58 \mathrm{nA}$. Positioning of the minielectrode was accomplished with a micromanipulator (resolution $50 \mu \mathrm{m}$ ).

Nitrification activity. Nitrification rates were obtained by measuring the changes of $\mathrm{NO}_{2}{ }^{-}$concentration in sediment samples containing allylthiourea (ATU) or sodium chlorate $\left(\mathrm{NaClO}_{3}\right)$ to inhibit the oxidation of $\mathrm{NH}_{4}{ }^{+}$and $\mathrm{NO}_{2}{ }^{-}$, respectively (Bianchi et al. $1992,1994)$. The upper $2 \mathrm{~cm}$ of the sediment samples was divided into 3 sets of triplicates subsamples $(30 \mathrm{~g})$, and each was mixed thoroughly with filtered bottom water (Whatman GF/F) in a 1 l polycarbonate bottle. One triplicate set of bottles was unamended (control). one received $10 \mathrm{mg} \mathrm{l}^{-1} \mathrm{ATU}$ (final conc.) and the third received $10 \mathrm{mM} \mathrm{NaClO}_{3}$. No substrate was added. The bottles were incubated in the dark with loosely fitted caps and without shaking at the in situ temperature in a Sanyo incubator Concentrations of $\mathrm{NO}_{2}^{-}$were measured every $4 \mathrm{~h}$ from zero time to $24 \mathrm{~h}$. The nitrification activity rate was calculated from data obtained during the linear $\mathrm{NO}_{2}{ }^{-}$or $\mathrm{NO}_{3}{ }^{-}$production phases in the first $12 \mathrm{~h}$ of incubation. The bottles were first vigorously shaken before $20 \mathrm{ml}$ samples were extracted into screw cap polyethylene tubes for centrifugation at $5000 \mathrm{rpm}(2150 \times \mathrm{g})$ for $15 \mathrm{~min}$. No filtration was performed in order to avoid the leaching of particulate matter retained on the filter The supernatant was fixed with $\mathrm{HgCl}_{2}$ and stored at $4^{\circ} \mathrm{C}$ in precombusted Pyrex flasks for later analysis within $48 \mathrm{~h}$. Analyses of $\mathrm{NO}_{2}^{-}$were performed as described for the water column and averaged for triplicates. The $\mathrm{NO}_{2}{ }^{-}$accumulation and consumption were linear in time $(p<0.05)$, indicating that little or no growth of nitrifying bacteria occurred during the incubation. The slope of the $\mathrm{NO}_{2}{ }^{-}$ curve in $\mathrm{NaClO}_{3}$ and ATU bottles gave respectively $\mathrm{NH}_{4}{ }^{+}$and $\mathrm{NO}_{2}{ }^{-}$oxidation rates in $\mu \mathrm{mol} \mathrm{N}$ per litre of wet sediment $\left(1^{-1}\right.$ WS $)$ and per day. The accuracy was given by the standard error of the slope and if no significant correlation was found the rates were considered to be zero.

Denitrification and dissimilatory nitrate reduction to ammonium (DAP) activities. A combination of an acetylene blockage technique to assay for denitrification and a ${ }^{15} \mathrm{~N}$ isotope tracer technique to measure dissimilatory nitrate reduction was performed. Subsamples $(5 \mathrm{ml}$ ) from $2 \mathrm{~cm}$ segments of the $8 \mathrm{~cm}$ wide core were transferred into $13 \mathrm{ml}$ tubes containing $5 \mathrm{ml}$ of natural sea water supplemented either with only chloramphenicol to prevent growth during incubation for the natural activities), or with chloramphenicol, glucose $\left(1 \mathrm{~g} \mathrm{l}^{-1}\right.$ ) and $\mathrm{KNO}_{3}(1 \mathrm{mM})$ (for the potential activities; according to Tiedje et al. 1989). All subsamples were inoculated with ${ }^{15} \mathrm{NO}_{3}{ }^{-}$. The amount of ${ }^{15} \mathrm{NO}_{3}{ }^{-}$ (97.4 at.\%; Isotec France) was added at a concentration lower than $10 \%$ of the guessed in-tube nitrate concentration. For calculation, the actual percentage was taken into account after measurement of the $\mathrm{NO}_{3}$ level during later analysis. No addition of $\mathrm{NH}_{4}{ }^{+}$was necessary to prevent nitrate assimilation, because of the high ammonium content in the sediment (higher than $100 \mu \mathrm{M}$ ). The tubes were sealed with rubber stoppers and anaerobic conditions obtained by flushing $\mathrm{N}_{2}$ through the tube for $2 \mathrm{~min}$. Acetylene, which inhibits the reduction of $\mathrm{N}_{2} \mathrm{O}$ to $\mathrm{N}_{2}$ (Balderston et al. 1976), was injected in the gas phase (final conc. $15 \mathrm{kPa}$ ) and the tubes were vortexed. Samples were incubated in the dark at in situ temperature for $0,1,3,5$ and $24 \mathrm{~h}$. After incubation, each tube was treated with $0.1 \mathrm{ml}$ of $1 \mathrm{M}$ $\mathrm{HgCl}_{2}$ solution, vigorously shaken by hand for $2 \mathrm{~min}$, and then centrifuged at $2000 \mathrm{rpm}(350 \times \mathrm{g})$ for $3 \mathrm{~min}$.

Denitrifying activity was considered as the linear initial rate of $\mathrm{N}_{2} \mathrm{O}$ accumulation. After incubation nitrous oxide was measured in the headspace and in the sea water A subsample $(2.5 \mathrm{ml})$ of the gas phase was injected into a $3 \mathrm{ml}$ pre-evacuated tube (Venoject. 
Terumo, Leuven, Belgiuml for later $\mathrm{N}_{2} \mathrm{O}$ analysis. Extraction of $\mathrm{N}_{2} \mathrm{O}$ ) from the liquid phase was carried out using the procedure of Chan \& Knowles (1979) modified by the technique of multiple equilibrium (Mac Aullife 1971). Nitrous oxide concentrations in the tubes were determined by gas chromatography (Girdel, series 30) using an electron capture detector. Chromatographic operating conditions were: $8 \mathrm{ft}$ (2.4 m) length 'Porapak Q' column (mesh 50/80); oven temperature, $80^{\circ} \mathrm{C}$ injector temperature, $180^{\circ} \mathrm{C}$; detector temperature, $250^{\circ} \mathrm{C}$. Nitrogen was used as carrier

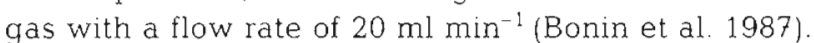

According to Tiedje's (1988) procedure, we determined the rate of nitrate ammonifying activity by monitoring the progressive increase in isotopic enrichment of ${ }^{15} \mathrm{NH}_{4}{ }^{+}$with time as the substrate $\left(\mathrm{NO}_{3}{ }^{-}\right)$was used. In the sediment, it is usually assumed that $\mathrm{NH}_{4}{ }^{+}$available to the bacteria is present in the pore water plus exchangeable- $\mathrm{NH}_{4}{ }^{+}$pools (i.e. extractable $\mathrm{NH}_{4}{ }^{+}$). Pore water was removed by centrifugation of sediments and $2.5 \mathrm{ml}$ of supernatant was collected in microdiffusion flasks. Then, $2 \mathrm{M} \mathrm{KCl}$ was added to the sediment pellet at a $\mathrm{KCl}$ :sediment proportion of $1: 1(\mathrm{~V}: \mathrm{v})$, the mixture was homogenised and then shaken for $1 \mathrm{~h}$ at $5^{\circ} \mathrm{C}$ (Laima 1993). The $2.5 \mathrm{ml}$ of $\mathrm{KCl}$ extractable pools obtained after centrifugation at $3000 \times g$ for $5 \mathrm{~min}$ from this mixture was added to the microdiffusion flask. The $\mathrm{NH}_{4}{ }^{+}$was removed by microdiffusion at $60^{\circ} \mathrm{C}$ as follows. The mixture was treated with $\mathrm{MgO}$ to convert $\mathrm{NH}_{4}{ }^{+}$to $\mathrm{NH}_{3}$, which was trapped on quarter pre-combusted Whatman GF/C filter acidified with $\mathrm{H}_{2} \mathrm{SO}_{4}$ $(50 \mu \mathrm{l}, 0.5 \mathrm{~N})$ (Brooks et al. 1989). The ammonium removal efficiency was greater than $98 \%$. Since the amount of nitrogen present in the sample was below the sensitivity of the mass spectrometer, a known quantity (1 $\mu \mathrm{mol})$ of unlabelled ammonium (carrier nitrogen) was added before microdiffusion. The amount of carrier nitrogen added was taken into account when calculating the ammonium production rates.

${ }^{15} \mathrm{~N}$ calculations. $\mathrm{N}$ isotope analysis involved interfacing an automatic N/C analyser (ANCA) to a triple collector isotope-ratio mass spectrometer (ANCA-MS Tracer mass, European Scientific)

To calculate the rate of the flux from dissolved nitrate to dissolved ammonium, the following equations derived by analogy with that of Dugdale \& Goering (1967) for a 2 compartment system were used:

$$
\text { DAP }=\frac{\left(\text { at. } \% \text { S excess in } \mathrm{NH}_{4}{ }^{+}\right)\left(\mathrm{NH}_{4}{ }^{+} \text {concentration }\right)}{\left(\text { at. } \% \text { enrichment in } \mathrm{NO}_{3}\right) \text { (incubation duration) }}
$$

where at $\% \mathrm{~S}$ excess in $\mathrm{NH}_{4}{ }^{+}$is the at. \% in excess of the sample without carrier, determined at the end of the incubation period from the measured at.\%.

When carrier nitrogen was used, the measured at. $\%$ of the analysed sample includes the contribution of the carrier as follows:

Measured at. $\%=\frac{\left(M_{\mathrm{s}}\right)\left(\text { at. } \% \text { S excess in } \mathrm{NH}_{4}{ }^{*}\right)+\left(M_{\mathrm{c}}\right)(\text { at. } \% \mathrm{C})}{\left(M_{5}+M_{\mathrm{c}}\right)}$

where $M_{\mathrm{s}}$ is the concentration of nitrogen in the sample, $M_{c}$ is the carrier nitrogen, at. \% $\mathrm{S}$ excess is the at. \% in excess of the sample without carrier, and at \% $\mathrm{C}$ is the at. \% of the carrier nitrogen (0.3662). The equation can be rearranged to calculate for at. $\% \mathrm{~S}$ excess in $\mathrm{NH}_{4}{ }^{+}$as follows:

$$
\begin{aligned}
& \text { At. \% } \mathrm{S} \text { excess in } \mathrm{NH}_{4}{ }^{+}= \\
& \frac{\text { (Méasured at. } \%)\left(M_{\mathrm{s}}+M_{\mathrm{c}}\right)-M_{\mathrm{c}}(\text { at. } \% \mathrm{C})}{\left(M_{\mathrm{s}}\right)}
\end{aligned}
$$

At. \% enrichment in $\mathrm{NO}_{3}{ }^{-}$is calculated according to:

At. \% enrichment in $\mathrm{NO}_{3}^{-}=$

$$
\text { total }{ }^{15} \mathrm{~N} \text { added }
$$

total ${ }^{15} \mathrm{~N}$ added + total ambient $\mathrm{N}$ substrate

Data anaiysis. Differences between the areas inside (Stn ZA) and outside the shellfish farming zones (Stn B), and the space-time variations of nitrogen processes in sediments were studied using a 3-way analysis of variance (ANOVA). Bartlett's test was employed to test for homogeneity of variance. Heteroscedastic data were transformed and then evaluated using ANOVA.

\section{RESULTS}

\section{Environmental data}

The study period began in April during the establishment of warm and dry meteorological conditions; the temperature and salinity increased from April to August (Fig. 2, Table 1). The lack of wind to circulate the water in July and August was responsible for a bottom anoxia which occurred in the deeper eastern part of the lagoon (depth $>6 \mathrm{~m}$ ) including the shellfish farming zone (Stn ZA). Later on, the period from September to early November corresponded to a rainy period with a drop of salinity down to 30.5 PSU. After November, the freshwater inputs were negligible, leading to the increase of salinity until April, with values close to levels measured in June (Fig. 2), but with a $-8^{\circ} \mathrm{C}$ temperature difference (Table 1 )

The concentrations of dissolved inorganic nitrogen (DIN) compounds in the water $\left(\mathrm{NH}_{4}{ }^{+}, \mathrm{NO}_{2}{ }^{-}, \mathrm{NO}_{3}{ }^{-}=\right.$ DIN) showed a similar pattern at both stations for all compounds but were higher at Stn ZA, particularly in November (Table 1). The concentrations increased from June to November 10 -fold or more and then dropped drastically in April.

Concerning the sediments, in June the \%OM was significantly higher at Stn ZA than at Stn B (Fig. 3). In 


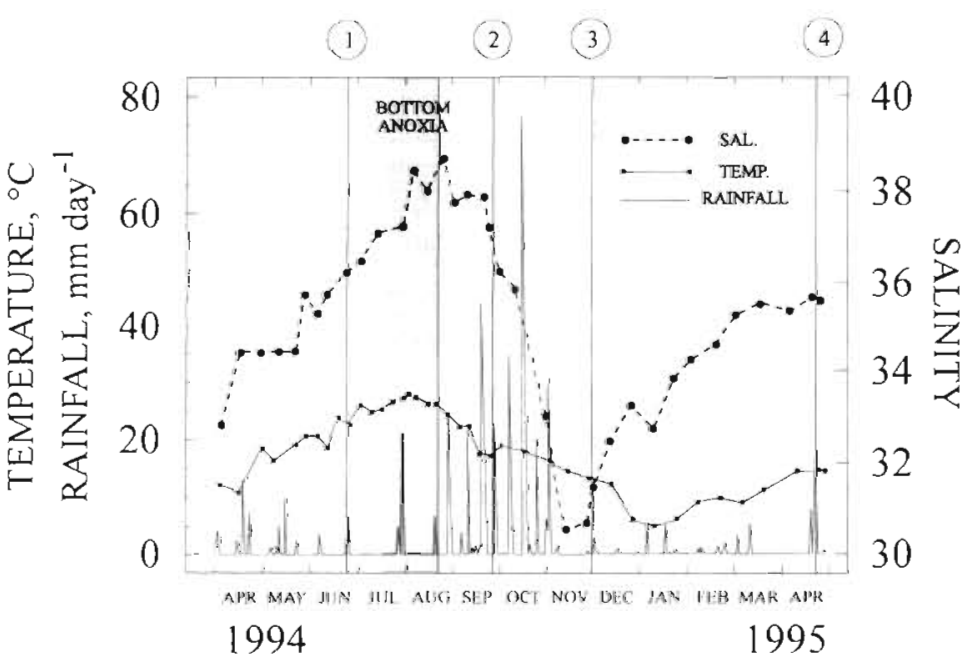

Fig. 2. Seasonal variation of rainfall monitored at Sète, salinity and temperature in the shell farming zone that contains Stn ZA, from April 1994 to April 1995. Sediment sampling times are indicated: 1, June 1994; 2, September 1994; 3, November 1994; 4, April 1995

September (after the bottom anoxia), \%OM ranged from $15 \%$ (top of sediment) to $10 \%$ (at $40 \mathrm{~mm}$ depth) for both stations. The sediments collected in November were characterised by the minimum \%OM $(<10 \%)$, while values comparable to those in June were recovered in April with a similar difference between the 2 stations.

Sediments from Stn B displayed positive redox potential (Eh) values which ranged from 50 to $100 \mathrm{mV}$ in June and were close to $200 \mathrm{mV}$ during the next 3 study periods. Eh values were stable with depth whatever the season. On the other hand, at Stn ZA, the Eh was variable with a rapid change from positive to negative values within the top $20 \mathrm{~mm}$ for the 3 first study periods. Moreover, a decrease from -100 to $-300 \mathrm{mV}$ was observed between June and September (Fig. 3). In No- vember, Eh values remained near -300 $\mathrm{mV}$. In April, Eh values were positive and quite stable with depth and were close to levels measured at $\operatorname{Stn} B$.

Oxygen profile measurements indicated that the depth of $\mathrm{O}_{2}$ penetration $\left(\left[\mathrm{O}_{2}\right]>\right.$ $6 \mu \mathrm{M}$ ) never exceeded $4 \mathrm{~mm}$ (Table 1) and was systematically deeper at Stn $B$ than at Stn $\mathrm{ZA}$. The maximum $\mathrm{O}_{2}$ penetration was recorded in April at the reference Stn B. the minimum being found in winter at $S t n$ ZA, where it was strictly limited to the interface itself.

Concentration of $\mathrm{NH}_{4}{ }^{+}$in pore water was stable with depth at Stn B. Pattern of changes with time of $\mathrm{NH}_{4}^{+}$concentrations were similar for the 2 stations: (1) increase from June to September (from 50 to $100 \mu \mathrm{M}$ and 220 to $550 \mu \mathrm{M}$ for Stns $\mathrm{B}$ and ZA, respectively), (2) stability in November, and then (3) in April, a drop to levels close to those reported in June.

\section{Bacterial activities}

Nitrification

Rates of nitrification ranged from 0 to $77 \mu \mathrm{mol} \mathrm{d}^{-1} \mathrm{l}^{-1}$ WS. The summer experiment (June) was characterised by insignificant nitrification rates both inside (Stn ZA) and outside (Stn B) the shellfish farming zone (Fig. 4A, B). At Stn ZA, both steps of nitrification in the sediment were only measurable in September, when the superficial layer rich in suspended particles was observed. In winter (November), the nitrification was enhanced at Stn $\mathrm{B}$, where the first step of nitrification $\left(\mathrm{NH}_{4}{ }^{+}\right.$oxidation; Fig. 4A) was 2.5 times higher than the second step $\left(\mathrm{NO}_{2}^{-}\right.$

Table 1. Concentrations of DIN in the bottom water and sediments, temperature and salinity in the bottom water and depth of $\mathrm{O}_{2}$ penetration in sediments $\left(\left[\mathrm{O}_{2}\right]>6 \mu \mathrm{M}\right)$ from June 1994 to April 1995 at Stris ZA and B

\begin{tabular}{|c|c|c|c|c|c|c|c|c|}
\hline & \multicolumn{2}{|c|}{ June 1994} & \multicolumn{2}{|c|}{ September 1994} & \multicolumn{2}{|c|}{ November 1994} & \multicolumn{2}{|c|}{ April 1995} \\
\hline & $\mathrm{ZA}$ & B & $\mathrm{ZA}$ & B & $\mathrm{ZA}$ & B & $\mathrm{ZA}$ & B \\
\hline \multicolumn{9}{|l|}{ Water } \\
\hline Temperature $\left({ }^{\circ} \mathrm{C}\right)$ & 22.1 & 22.1 & 18.6 & 18.6 & 15.5 & 15.5 & 14.1 & 14.1 \\
\hline Salinity (PSU) & 36.1 & 36.1 & 38.0 & 38.0 & 34.0 & 34.0 & 37.3 & 37.3 \\
\hline$\left[\mathrm{NH}_{4}^{+}\right](\mu \mathrm{M})$ & 0.66 & 0.34 & 5.3 & 3.4 & 7.7 & 1.62 & 0.84 & 0.69 \\
\hline$\left[\mathrm{NO}_{2}^{-}\right](\mu \mathrm{M})$ & 0.07 & 0.09 & 0.48 & 0.37 & 1.32 & 1.28 & 0.14 & 0.10 \\
\hline$\left[\mathrm{NO}_{3}^{-}\right](\mu \mathrm{M})$ & 0.12 & $<0.05$ & 5.8 & 2.6 & 11.9 & 9.5 & 0.68 & 0.15 \\
\hline \multicolumn{9}{|l|}{ Sediment } \\
\hline $\mathrm{O}_{2}$ penetration (mm) & 1.7 & 2.7 & 12 & 3.2 & 0.1 & 2.0 & 1.5 & 4.0 \\
\hline$\left[\mathrm{NO}_{2}^{-}\right](\mu \mathrm{M})$ & $<0.05$ & 0.1 & 0.09 & 0.11 & 1.3 & 1.3 & 0.43 & 1.1 \\
\hline$\left[\mathrm{NO}_{3}^{-}\right](\mu \mathrm{M})$ & $<0.05$ & $<0.05$ & $<0.05$ & $<0.05$ & 3.0 & 0.35 & 0.67 & 1.0 \\
\hline
\end{tabular}



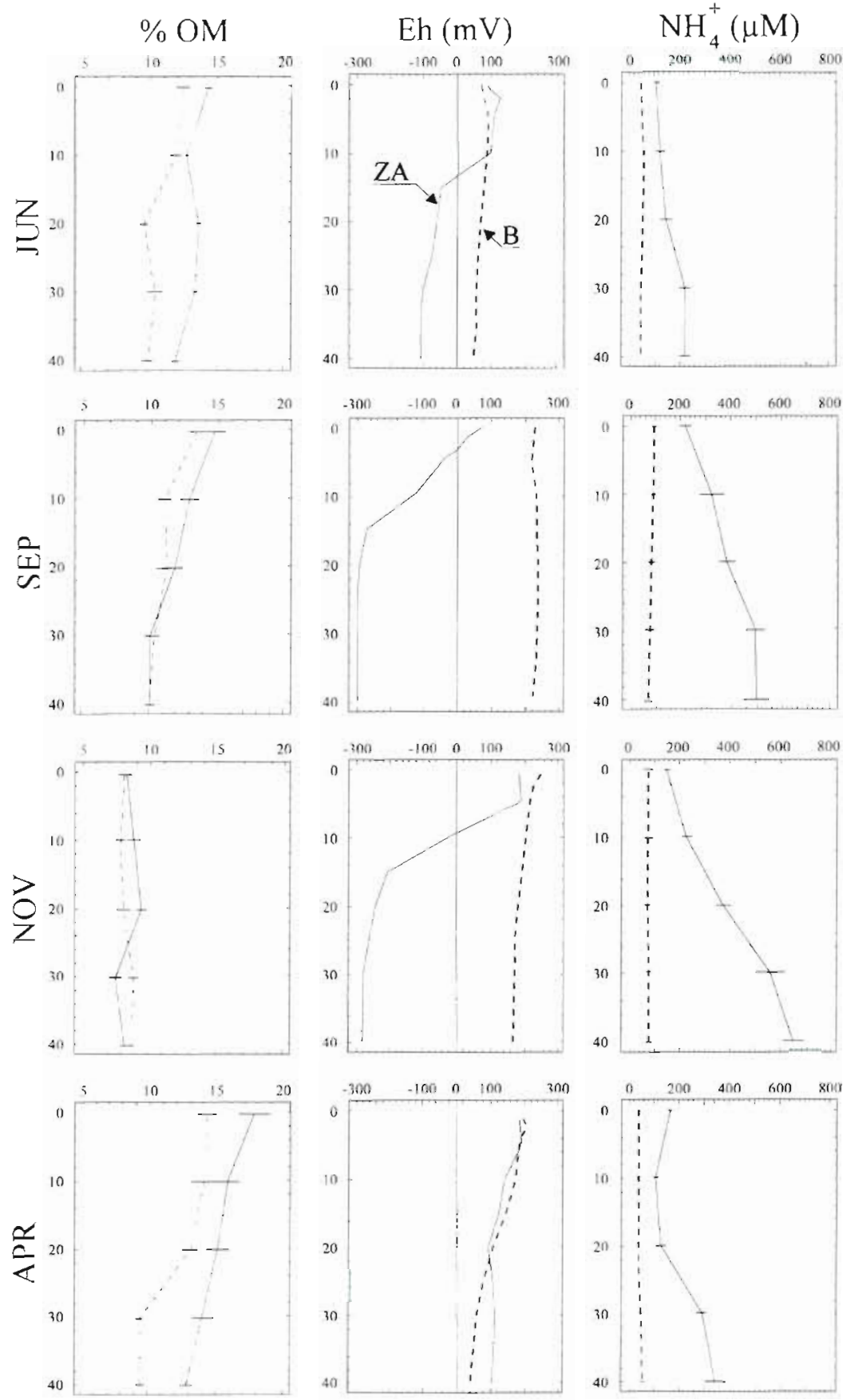

Fig. 3. Dry organic matter (\%OM), distribution of redox potential (Eh), and concentration of ammonium in porewater $\left(\mathrm{NH}_{4}{ }^{+}\right)$in the upper $4 \mathrm{~cm}$ of sediment at Stn ZA (solid line) and Stn B (dashed line), from June 1994 to April 1995.

$y$-axis: depth in sediment $(\mathrm{mm})$. Values are mean \pm standard error $(\mathrm{n}=3)$

\section{Dissimilatory processes: DAP and denitrification}

In June, both the denitrification and DAP natural rates were very weak, averaging 0.26 and $1.57 \mu \mathrm{mol} \mathrm{d} \mathrm{d}^{-1} \mathrm{I}^{-1}$ WS, respectively, in Stn B (Fig 4C, D). No significant differences were found between Stns ZA and B. In September, no denitrification activity was found at Stns ZA and B. On the other hand, highly enhanced DAP rates were measured, particularly at Stn ZA (249 \pm $33 \mu \mathrm{mol} \mathrm{d} \mathrm{d}^{-1} \mathrm{l}^{-1} \mathrm{WS}$; mean $\pm \mathrm{SE}$ ). In November, denitrifying rates were $2.1 \pm$ 0.4 and $0.7 \pm 0.1 \mu \mathrm{mol} \mathrm{d} \mathrm{d}^{-1} \mathrm{l}^{-1}$ WS at Stns ZA and B, respectively, corresponding to the highest values obtained (Fig. 4C). At this sampling time, the DAP rates at the 2 stations dropped to very low values, corresponding to those found in June (Fig. 4D). Later on, between November and April, the denitrifying rates were back within the same range (around $0.6 \mu \mathrm{mol} \mathrm{d} \mathrm{d}^{-1} \mathrm{l}^{-1}$ WS) at both stations, whereas no significant changes in DAP rates were found in sediments.

For pore water $\mathrm{NO}_{3}{ }^{-}$and $\mathrm{NO}_{2}{ }^{-}$sediment concentrations never higher than 3.0 $\mu M_{4}$ natural DAP and denitrifying activity may be very low. In view of this, we decided to complete the study by also taking into account their potential rates. Moreover, because of the oxygen penetration in the studied 0 to $2 \mathrm{~cm}$ layer (Table 1), which inhibits both the DAP and denitrifying activities, the activity rate measurements were extended down to $4 \mathrm{~cm}$ depth and separated into 2 layers (L1: 0 to $2 \mathrm{~cm}$; L2: 2 to $4 \mathrm{~cm}$ ). The natural denitrification and DAP rates measured in the 2 to $4 \mathrm{~cm}$ layer of the sediments of Stns ZA and B were of the same order of magnitude as those measured in the upper 0 to $2 \mathrm{~cm}$ layer (Table 2) and presented the same patterns of changes with time (data not shown).

The fluctuations with time of potential denitrification and DAP rates in the 2 layers of sediments from Stns $\mathrm{ZA}$ and $\mathrm{B}$ are presented in Fig. 5. In June, the potential denitrifying rates measured $\left(<23 \mu \mathrm{mol} \mathrm{d}{ }^{-1} 1^{-1}\right.$ WS $)$ were higher at Stn $B$ than at Stn ZA in both layers of sediments (Fig. 5A, B). At the same time, the potential DAP oxidation; Fig. 4B). These high rates of ammonium oxidation were also demonstrated by the significant net nitrifying activity $\left(23 \mu \mathrm{mol}\right.$ of $\mathrm{N}-\mathrm{NO}_{2}$ produced $\mathrm{d}^{-1} \mathrm{I}^{-1}$ WS) in controls at Stn B in November (data not shown). A weaker but significant activity was also obtained outside the shellfish farming zone (Stn B) in April. 

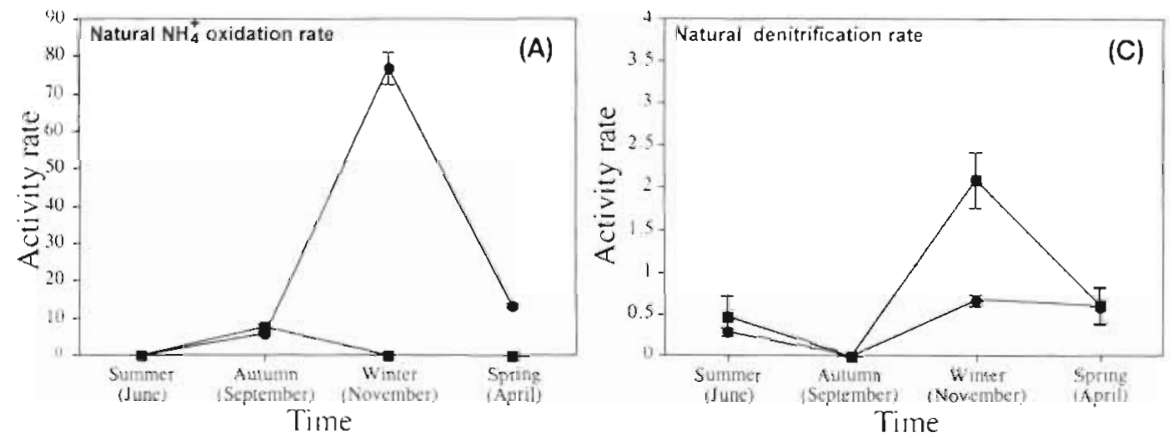

Time
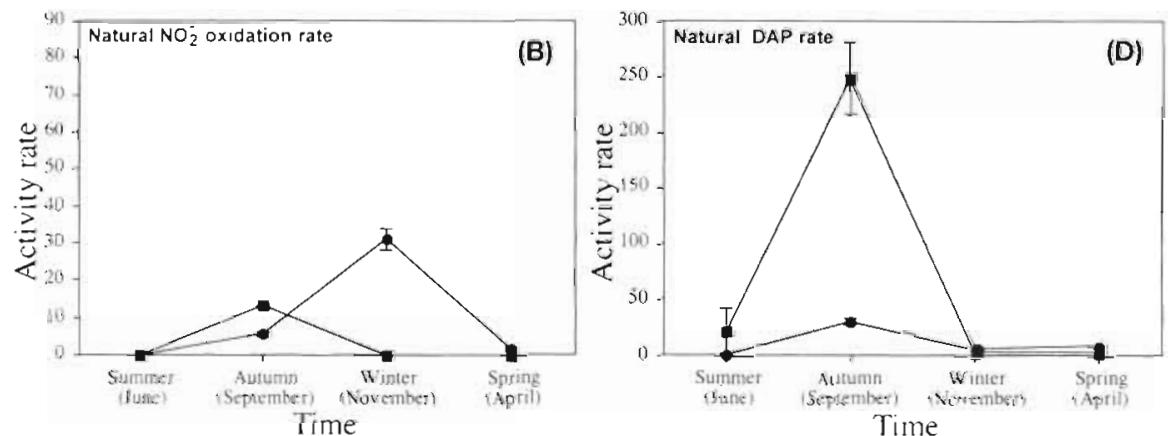

Fig. 4. Natural nitrification [both (A) $\mathrm{NI}_{4}{ }^{*}$ oxidation and (B) $\mathrm{NO}_{2}^{-}$oxidation steps). (C) denitrification and (D) DAP rates in the 0 to $2 \mathrm{~cm}$ layer of the different sediments, from June 1994 to April 1995. Values are mean values \pm standard errors $(n=3)$ expressed in $\mu \mathrm{mol} \mathrm{d}^{-1} \mathrm{l}^{-1}$ WS (wet sediment). (-) Stn ZA; $(\bullet)$ Stn B rates at Stns ZA and B were about 27 and $40 \mu \mathrm{mol} \mathrm{d}^{-1}$ $\mathrm{l}^{-1}$ WS in the 0 to $2 \mathrm{~cm}$ (Fig. $5 \mathrm{C}$ ) and 2 to $4 \mathrm{~cm}$ layer (Fig. 5D), respectively. In September, the activity rates were either slightly (to $40 \mu \mathrm{mol} \mathrm{d} \mathrm{d}^{-1} \mathrm{l}^{-1} \mathrm{WS}$; potential denitrification) or strongly enhanced (to $1300 \mu \mathrm{mol} \mathrm{d} \mathrm{d}^{-1}$ $1^{-1}$ WS; potential DAP) at the 2 sites. In November, the potential activity rates came back within the same range as that measured in June. In April, both denitrification and DAP rates showed their highest values.

A 3-way ANOVA was applied to the data, in order to determine the space-time variations of bacterial activities (Table 2).

\section{DISCUSSION}

The wide fluctuations of environmental conditions, including the temperature, organic matter and DIN content, lead to considerable differences in nitrification, denitrification and DAP rates measured in the sediment of different ecosystems (Table 3). Because of the large variability in the values proposed in the literature, the nitrification, denitrification and DAP rates measured in the sediment of Thau lagoon sediment fall within the same range

The results obtained have shown significant changes for the different bacterial processes with time and station localisation.
Table 2. ANOVA analysis comparing the stations (Stns ZA and B), time (season) and sediment layers for the 3 bacterlal $N$ processes. When a significant effect is found with 'Time', the season with maximal activity is indicated. When a significant effect is found with 'Station' or 'Layer', the mean stimulation factor is indicated. NS: not significant; L1: 0 to $2 \mathrm{~cm}$ sediment core layer; L2: 2 to $4 \mathrm{~cm}$ sediment core laver; ND: not determined; ${ }^{\cdots} p<0.001$; ${ }^{\prime} p<$ $0.01 ; \cdot p<0.05$

\begin{tabular}{|c|c|c|c|}
\hline & Station & Time & Layer \\
\hline \multicolumn{4}{|l|}{ Natural rates } \\
\hline $\mathrm{NH}_{4}{ }^{+}$oxidation & $\mathrm{ZA}<\mathrm{B} \cdots[\times 12\}$ & Winter $\cdots$ & ND \\
\hline $\mathrm{NO}_{2}^{-}$oxidation & $\mathrm{ZA}<\mathrm{B} \cdots \mid \times 3\rfloor$ & Winter $\cdots$ & ND \\
\hline Denitrification & $Z A>B \cdots|\times 3.7|$ & Winter $\cdots$ & $N S(p=0.49)$ \\
\hline DAP & $Z A>B^{\cdot} \quad[\times 3.3 \mid$ & Autumn $\cdots$ & $N S(p=0.29)$ \\
\hline \multicolumn{4}{|l|}{ Potential rates } \\
\hline Denitrification & $\mathrm{ZA}<\mathrm{B} \cdots[\times 1.4]$ & Autumn, spring $\cdots$ & $\mathrm{L}_{1}>\mathrm{L} 2 \cdot \cdots[\times 1.5]$ \\
\hline DAP & $Z A>B \cdots|\times 1.5|$ & Autumn, spring $\cdots$ & $\mathrm{L} 1>\mathrm{L} 2^{\circ}[\times 2]$ \\
\hline
\end{tabular}



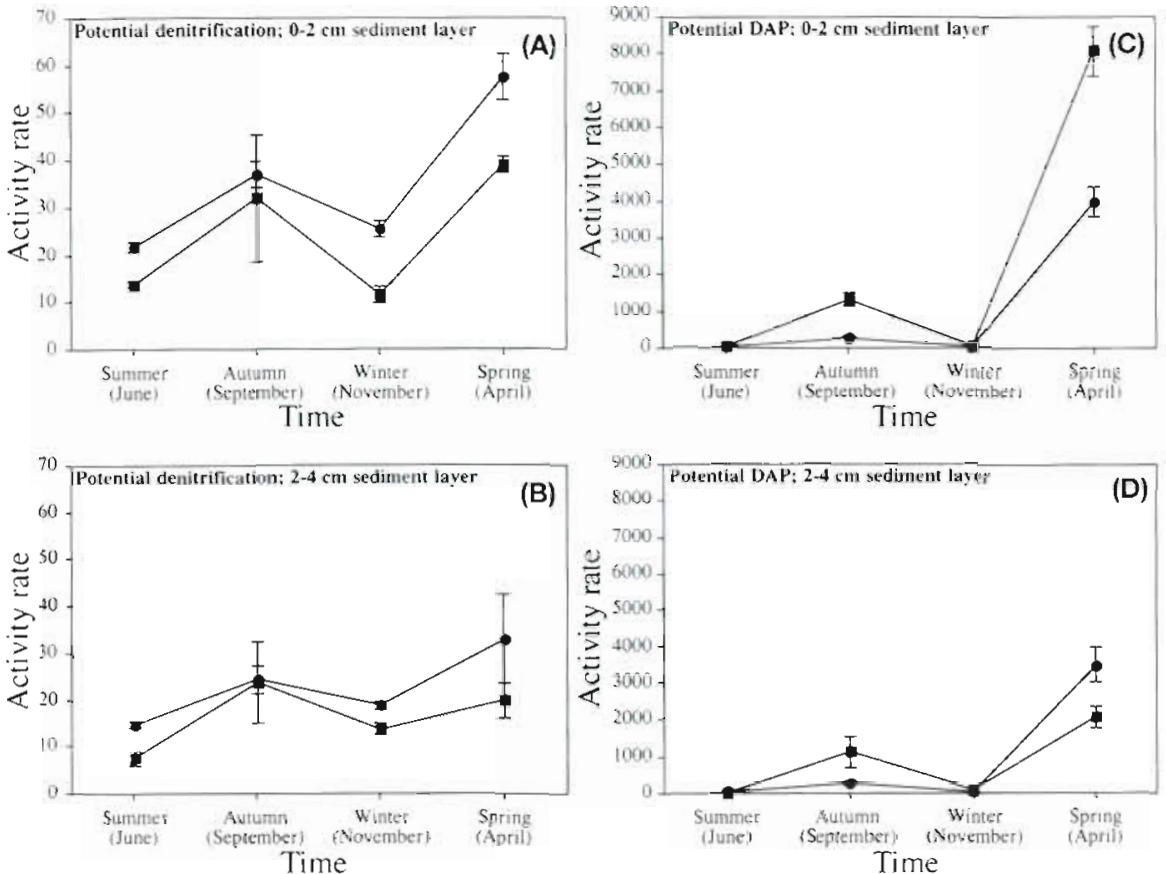

Fig. 5. Potential $\{A, B\}$ denitnfication and $(C, D)$ DAP rates in the (A, C) 0 to $2 \mathrm{~cm}$ and $(B, D) 2$ to $4 \mathrm{~cm}$ layers of the different sediments, from June 1994 to April 1995. Values are mean values \pm standard errors $(n=3)$ expressed in $\mu \mathrm{mol} \mathrm{d}^{-1}$

$\mathrm{J}^{-1}$ WS. (-) Stn $\mathrm{ZA} \mathrm{A}_{i}(\bullet) \operatorname{Stn} \mathrm{B}$
Table 3. Nitrification, denitrification and DAP rates in various sediments ( $\mu \mathrm{mol} \mathrm{l}^{-1} \mathrm{~d}^{-1}$ ). Both natural and experimentally enriched $(\bullet)$ activities are presented

\begin{tabular}{|ll|}
\hline Bacterial process & Source \\
\hline Nitrification & \\
2.86 & Koike \& Hattori (1978) \\
$0-150$ & Henriksen (1980) \\
$15-70$ & Henriksen et al. (1981) \\
$4.5^{-11.0}$ & Szwerinski (1981) \\
760 & Herbert (1986) \\
0.42 & Enoksson \& Samuelsson (1987) \\
$0-77$ & Present study \\
Denitrification & \\
$50-435^{\circ}$ & Sorensen (1978a) \\
17.5 & Sorensen (1978b) \\
60 & Sørensen et al. (1979) \\
$0-96$ & Andersen et al. (1984) \\
$790^{\circ}$ & Goeyens et al. (1987) \\
$0-94.8$ & Raymond (1992) \\
$23.2-35.4$ & G.lbert (1994) \\
$0-19.8$ & Omnes (1996) \\
$0-2.9$ & Present study \\
$7.6-57.5^{\circ}$ & Present study \\
DAP & \\
$120-750^{\circ}$ & Sorensen (1978a) \\
$9-267$ & Blackburn (1979) \\
34 & Jones et al. (1982) \\
$2.8-110.4^{\circ}$ & Enoksson \& Samuelsson (1987) \\
$790^{\circ}$ & Goeyens et al. (1987) \\
$1.3-83.2$ & Omnes (1996) \\
$1.9-249^{\circ}$ & Present study \\
$20.3-8054^{\circ}$ & Present study \\
& \\
\hline
\end{tabular}

ranges from 1.1 to $6.2 \mathrm{mM}$ (Henriksen \& Kemp 1988) and as the oxygen penetration was only a few millimeters (Table 1), it is likely that nitrification in sediments was limited to the first centimeter. Due to conditions of low oxygen availability, $\mathrm{H}_{2} \mathrm{~S}$ inhibition and competition for $\mathrm{NH}_{4}{ }^{+}$(Hansen et al. 1981, Joye \& Hollibaugh 1995, Jensen at al. 1996), the nitrification rates decrease during summer

In autumn (September), the high salinity reported showed that the increase of DIN concentrations in the water could not be explained by freshwater inputs from the surrounding land. The mineralisation of the organic matter due to the primary producers of summer communities and $\mathrm{NH}_{4}{ }^{+}$release from sediments after the anoxic period could have induced an increase in $\mathrm{NH}_{4}^{+}$concentrations in the water column, which would have probably enhanced pelagic nitrification (Berounsky \& Nixon 1985, Collos et al. 1988), and thus increased $\mathrm{NO}_{3}$ concentrations. Higher $\mathrm{NO}_{3}{ }^{-}$concentrations at Stn ZA suggest that higher levels of $\mathrm{NH}_{4}{ }^{+}$, coming from filter feeders and their epibiota, stimulated nitrification at the filter-feeder-water interface (Mazouni 1995), and then the $\mathrm{NO}_{3}{ }^{-}$produced was available for both dissimilatory processes (denitrification and DAP). However, at the same time, the highest $\%$ OM measured in the upper $20 \mathrm{~mm}$ of sediment confirmed the sedimentation of the phytoplankton bloom. In the presence of this organic matter supply, the elevation of the $\mathrm{C} / \mathrm{N}$ ratio in sediments, already shown in autumn in the shellfish farming zone (Barranguet et al. 
1994), may have favoured DAP compared to denitrification (Smith 1982, Tiedje et al. 1982, Rehr \& Klemme 1989) that is predominant in low $\mathrm{C} / \mathrm{N}$ conditions (Bowman \& Focht 1974, Grabinska-Loniewska et al. 1985, Thomas \& Lloyd 1995). As shown by the ANOVA results, in September (autumn), only the DAP was stimulated in sediments, denitrification being even lower than previously observed.

In November (winter), the 2 stations showed the same decrease in salinity, which reflected the influence of freshwater inputs from the watershed. Between April 1994 and April 1995, the total rainfall on the watershed was $456 \mathrm{~mm}$, in comparison to a mean $( \pm \mathrm{SE})$ of $623 \pm 196 \mathrm{~mm}$ from 1961 to 1995 . Therefore, the study period could not be considered as exceptionally wet, and a salinity of below 30 PSU with an $\mathrm{NO}_{3}{ }^{-}$ concentration $>10 \mu \mathrm{M}$ is reported to be common in this ecosystem (Tournier et al. 1982). The high $\mathrm{NO}_{3}{ }^{-}$concentrations in November probably induced diffusion into the sediment, which explains the significant levels of $\mathrm{NO}_{3}{ }^{-}$recorded in the pore water The minimum $\% O M$ reported in November indicates efficient remineralisation. The combination of $\mathrm{NO}_{3}{ }^{-}$supply (by precipitation and streaming) and low levels of organic matter (inducing low $\mathrm{C} / \mathrm{N}$ conditions) may thus have stimulated denitrification in the sediment, especially at Stn ZA. Moreover, if the nitrification rate was maximal, stronger stimulation of the $\mathrm{NH}_{4}{ }^{+}$oxidation compared to the $\mathrm{NO}_{2}{ }^{-}$oxidation tended to induce accumulation of $\mathrm{NO}_{2}{ }^{-}$that can be used as substrate by denitrifying bacteria. In such conditions, the DAP rates were minimum. By comparing the patterns of change of the 2 dissimilatory nitrate reducing process rates, we have provided evidence, as already shown by Jørgensen (1989) and Zimmerman \& Benner (1994), of some inverse seasonal variations between denitrification and DAP. Thus, it appears that the maximum nitrification rate (for both $\mathrm{NH}_{4}{ }^{+}$oxidation and $\mathrm{NO}_{2}^{-}$oxidation) took place in November, suggesting a high rate of production of $\mathrm{NO}_{3}{ }^{-}$substrate for the dissimilatory nitrate reducing processes, as measured in both water and sediment (Table 1). The maximum denitrification rate was also recorded at the same season. However, the highest DAP rate had already appeared in autumn when $\mathrm{NO}_{3}$ concentrations were lower

\section{Effect of shellfish farming activity}

The ANOVA results (Table 2) also showed significant influence of the shellfish farming on bacterial activity. The dissimilatory processes (denitrification and DAP) were 3.5 times higher at Stn ZA than at Stn B. On the other hand, it appeared that Stn B presented an enhanced nitrification rate $\left(\times 12\right.$ for $\mathrm{NH}_{4}{ }^{+}$ oxidation; $\times 3$ for $\mathrm{NO}_{2}^{-}$oxidation) compared to that at Stn ZA. In fact, if the sediments were essentially similar, both being dominated by fine particles, sediments at Stn ZA had a slightly higher \%OM, which reflects the greater deposition rates characteristic of shell farming areas (Dame et al. 1979). Moreover, the zone of rapid change from positive to negative Eh values situated in the upper $2 \mathrm{~cm}$ at $\mathrm{Stn} \mathrm{ZA}$ indicated an organic enrichment in these sediments (Sampou \& Oviatt 1991) compared with sediments from Stn $\mathrm{B}$. The marked difference in concentration profiles of $\mathrm{NH}_{4}{ }^{+}$between sediments from Stns ZA and B can be seen as resulting from different organic inputs (Sloth et al. 1995) combined with different nitrogen processes occurring in sediments (Enoksson \& Samuelsson 1987). Because of oxygenated conditions at Stn $\mathrm{B}$, aerobic nitrification could be observed. In contrast, the more reduced conditions at Stn ZA were more favourable for the anaerobic $N$ processes (denitrification and DAP). In both stations, the end-product partitioning of dissimilatory nitrate reduction between nitrogen gas and ammonium was favourable to the DAP process (Fig. 4), suggesting that in the studied sediments, most of the nitrate was reduced to ammonium and recycled. Kaspar et al. (1985) estimated nitrate ammonification from the overall nitrate reduction minus denitrification. They also concluded that denitrification was the main dissimilatory nitrate reducing process, representing $76 \%$ of total nitrate reduction at the mussel farm and $93 \%$ at a reference site.

While the natural denitrification and DAP rates show the same pattern for the 2 sites, the ANOVA results obtained for the potential rates are different (Table 2), In contrast to the natural rate, the potential denitrification rate (corresponding to the enzyme content) in Stn ZA sediment was 1.4 times lower than at Stn B (Table 2), indicating the essential role of environmental conditions, such as carbon content, in the stimulation of the denitrification at Stn ZA, as already suggested by Kaspar et al. (1985). On the other hand, as for the natural rate, the potential DAP rate was higher at Stn B. For both denitrification and DAP, the 2 sites sediments show similar natural rates in the 2 studied layers ( 0 to 2 and 2 to $4 \mathrm{~cm}$ ), even if the respective potential rates were higher in the first $(0$ to $2 \mathrm{~cm})$ than in the second layer ( 2 to $4 \mathrm{~cm}$ ).

\section{Conclusion}

The changes in environmental conditions associated with the shellfish farming significantly influence the nitrogen cycle at the water-sediment interface of the Thau lagoon. The shellfish farming activity causes a lowering of the nitrification rate, whereas dissimilatory 
nitrate reducing processes are stimulated. If the dissimilatory nitrate reducing processes are enhanced in such an ecosystem, denitrification remains a minor process versus DAP, suggesting that the loss of nitrogen for primary production is minimal. The DAP process maintains nitrogen available as ammonium, which plays a crucial role in the productivity of the coastal ecosystem.

Acknowledgements. The authors are grateful to F. Dagault, N. Garcia, C. Juge and D. Raphel for their technical assistance. This work is a contribution of the Oxythau Project from the 'Programme National d'Océanographie Cotière'

\section{LITERATURE CITED}

Andersen TK, Jensen MH, Sørensen J (1984) Diurnal variation of nitrogen cycle in coastal marine sediments I. Denltrification. Mar Biol 83:171-176

Balderston WL, Sherr B, Payne WJ (1976) Blockage by acetylene of nitrous oxide production in Pseudomonas perfectomarinus. Appl Environ Microbiol 31:504-508

Barranguet C, Alliot E, Plante-Cuny MR (1994) Benthic microphytic activities at two Mediterranean shellfish cultivation sites with reference to benthic fluxes. Oceanol Acta 17(2):211-221

Berounsky VM, Nixon SW (1985) Eutrophication and the rate of net nitrification in a coastal marine ecosystem. Estuar Coast Shelf Sci 20:773-781

Bianchi M, Bonin P, Feliatra (1994) Bacterial nitrification and denitrification rates in the Rhone river plume (northwestern Mediterranean. Sea). Mar Ecol Prog Ser 103:197-202

Bianchi M. Marty D. Teyssié JL, Fowler SW (1992) Strictly aerobic and anaerobic bacteria associated with sinking particulate matter and zooplankton fecal pellets. Ma.r Ecol Prog Ser 88:55-60

Blackburn TH (1979) Method for measuring rates of $\mathrm{NH}_{4}{ }^{+}$ turnover in anoxic marine sediments, using a ${ }^{15} \mathrm{~N}-\mathrm{NH}_{4}{ }^{*}$ dilution technique. Appl Environ Microbiol 37:760-765

Blackburn TH, Lund BA, Krom MD (1988) C-and N-mineralization in the sediments of earthen marine fishponds. Mar Ecol Prog Ser 44:221-227

Bonin P, Gilewicz M, Bertrand JC (1987) Dentrification by a marine bacterium Pseudomonas nautica strain 617 Ann Inst Pasteur Microbiol 138:371-383

Bowman RA, Focht DD (1974) The influence of glucose and nitrate concentrations upon denitrification rates in sandy soils. Soil Biol Biochem 6:297-301

Brooks PD. Stark JM, McInteer BB, Preston T (1989) Diffusion method to prepare soil extracts for automated nitrogen-15 analysis. Soil Sci Soc Am J 53:1707-1711

Chan YK, Knowles R (1979) Measurement of denitrification in two freshwater sediments by an in situ acetylene inhibition method. Appl Environ Microbiol 37 $1067-1072$

Collos Y, Linley EAS, Fnckha MG, Ravall B (1988) Phytoplankton death and nutrification at low temperatures. Estuar Coast Shelf Sci 27:341-347

Dame RF, Zingmark RG, Nelson D (1979) Filter feeder coupling between the estuarine water column and benthic subsystems. In: Kennedy VS (ed) Estuarine perspectives. Academic Press, New York, p 521-526

Dugdale RC, Goering JJ (1967) Uptake of new and regenerated forms of nitrogen in primary productivity. Limnol Oceanogr 12:196-296
Enoksson V, Samuelsson MO (1987) Nitrification and dissımılatory ammonium production and their effects on nitrogen flux over the sediment-water interface in bioturbated coastal sediments. Mar Ecol Prog Ser 36:181-189

Gerbal M, Verlaque M (1995) Macrophytobenthos de substrat meuble de l'étang de Thau (France, Méditerranée) et facteurs environnementaux associés. Oceanol Acta 18 : $557-571$

Gilbert F (1994) Influence de la bioturbation sur l'activité dénitrifiante dans des sédiments marins côtiers. Effet d'un apport exogène de matière organique: les hydrocarbures. These de l'Université d'Aix-Marseille II, ANRT-Grenoble 94/AlX2/2053 (in French)

Goeyens L, De Vries RTP, Bakker JF, Helder W (1987) An experiment on the relative importance of denitrification. nitrate reduction and ammonification in coastal marine sediment. Neth J Sea Res 21:171-175

Grabinska-Loniewska A, Slomezynski T, Kanska Z (1985) Denitrification studies with glycerol as a carbon source. Water Res 12:1471-1477

Guelorget O, Perthuisot JP, Lamy N, Lefebvre A (1994) Structure et organisation de l'étang de Thau d'après la faune benthique (macrofaune, méiofaune). Relations avec le confinement. Oceanol Acta 17:105-114

Hansen JI, Henriksen K, Blackburn TH (1981) SeasonaI distnbution of nitrifying bacteria and rates of nitrification in coastal marine sediments. Microb Ecol 7:297-304

Henriksen K (1980) Measurement of in situ rates of nitrification in sediment. Microb Ecol 6:329-337

Henriksen K, Hansen JI, Blackburn TH (1981) Rates of nitrification, distribution of nitrifying bacteria, and nitrate fluxes in different types of sediment from Danish waters. Mar Biol 61:299-304

Henriksen K, Kemp WM (1988) Nitrification in estuarine and coastal marime sediments. In: Blackburn $H$, Sorensen $J$ (eds) Nitrogen cycling in coastal marine environment Wiley, New York, p 207-250

Herbert RA (1986) Nitrate respiration and nitrification in estuarine sediments. In: Beucher $M$, et al. (eds) 2nd Int Colloq Mar Bacteriol, Brest, October 1984, GERBAM-France, CNRS, IFREMER. Actes Colloq Ifremer 3:277-281

Jenkins MC, Kemp WM (1984) The coupling of nitrification and denitrification in two estuarine sediments. Limnol Oceanogr 29:609-619

Jensen KM, Jensen MH, Kristensen E (1996) Nitrification and denitrification in Wadden Sea sediments (Könıshafen, Island of Sylt, Germany) as measured by nitrogen isotope pairing and isotope dilution. Aquat Microb Ecol 11 $181-191$

Jones JG. Simon BM, Horsley RW (1982) Microbiological sources of ammonıa in treshwater lake seciments. J Gen Microbiol 128:2823-2831

Jørgensen BB, Sorensen $\mathrm{J}$ (1985) Seasonal cycles of $\mathrm{O}_{2}, \mathrm{NO}_{3}{ }^{-}$ and $\mathrm{SO}_{1}{ }^{2-}$ reduction in estuarine sediments: the significance of an $\mathrm{NO}_{3}$ reduction in spring. Mar Ecol Prog Ser $24: 65-7.4$

Jørgensen KS (1989) Annual pattern of denitrification and nitrate ammonification in estuarine sediment. Appl Env1ron Nicrobiol 55:1841-1847

Jørgensen KS, Sørensen J (1988) Two annual maxima of nitrate reduction and denitrification in estuarine sediment (Norsminde Fjord, Denmark) . Mar Ecol Prog Ser 48:147-155

Joye SB, Hollibaugh JT (1995) Influence of sulfide inhibition on nitrification on nitrogen regeneration in sediments. Sclence 270:623-625

Kaspar HF, Gillespie PA, Boyer IC, Mackenzie AL (1985) Effects of mussel aquaculture on the nitrogen cycle and 
benthic communities in Kenepuru Sound, Marlborough Sounds, New Zealand. Mar Bıol 85:127-136

Koike I, Hattori A (1978) Simultaneous determinations of nitrification and nitrate reduction in coastal sediments by a ${ }^{15} \mathrm{~N}$ dilution technique. Appl Environ Microbiol 35: $853-857$

Koroleff $F$ (1976) Determination of nutrients. In: Grasshoff $\mathrm{K}$ (ed) Methods of seawater analysis. Verlag Chemie, Weinheim, p 117-182

Laima MIJC (1993) Recovery of ${ }^{15} \mathrm{NH}_{4}{ }^{+}$in labelling experiments on coastal marine sediments. Mar Chem 44:31-42

Mac Aullife C (1971) GC determination of solutes by multiple phase equilibration. Chem Tech 1:46-51

Mazouni N (1995) Influence des élevages ostréicoles sur le fonctionnement d'un écosystème lagunaire méditerranéen. Etude in situ de l'influence des filtreurs (coquillages et épibiontes) sur les flux de matières particulaire et dissoute. Thèse de Doctorat de l'Université d'Aix-Marseille II, ANRT-Grenoble 95/Aix2/2096

Mazouni N, Gaetner JC, Deslous-Paoll JM, Landrein S, d'Oedenberg MG (1996) Nutrient and oxygen exchanges at the water-sediment interface in a shellfish farming lagoon (Thau, France). J Exp Mar Biol Ecol 205:91-113

Mesnage V. Picot B (1995) The distribution of phosphate in sediments and its relation with eutrophication of a Mediterranean coastal lagoon. Hydrobiologia 297:29-41

Nixon SW (1981) Remineralization and nutrient cycling in marine coastal ecosystems. In: Neilson BJ, Cronon LE (eds) Estuaries and nutrients. Humana Press, Clifton, NJ, p $111-138$

Omnes P (1996). Mise en évidence de la réduction dissimilatrice du nitrate en ammonium en mllieu côtier. Utilisation du marquage isotopique à l'azote 15. Application in situ aux systèmes particulaires et sédimentaires en Médrterranée. Thèse de l'Université d'Aix-Marseille [l, ANRTGrenoble 96/4ix2

Picot B, Péna G, Casellas C, Bondon D, Bontoux J (1990) Interpretation of the seasonal variations of nutrients in a Mediterranean lagoon: Etang de Thau. Hydrobiologia $207: 105-114$

Raymond N (1992) Réponses métaboliques des communautés bactériennes anaérobies à un apport de produits pétroliers dans un sédiment marin. Thèse de Doctorat de l'Université d'Aix-Marseille II, ANRT-Grenoble 92/Aix2/2048

Rehr B, Klemme JH (1989) Competition for nitrate between denitrifying Pseudomonas stutzeri and nitrate ammonifying enterobacteria. FEMS Microbiol Ecol 62:51-58

Ryther JH, Dunstan WM (1971) Nitrogen, phosphorus, and eutrophication in the coastal marine environment. Science 171:1008-1013

Sampou P, Oviatt CA (1991) Seasonal patterns of sedimentary carbon and anaerobic respiration along a simulated eutrophication gradient. Mar Ecol Prog Ser 72:271-282

Seitzinger SP (1988) Denitrification in freshwater and coastal marine ecosystems: ecological and geochemical significance. Limnol Oceanogr 33:702-724
Sloth NP, Blackburn TH, Hansen LS, Risgaard-Petersen N, Lomstein BA (1995) Nitrogen cycling in sediments with different organic loading. Mar Ecol Prog Ser 116:163-170

Smith MS (1982) Dissimilatory reduction of $\mathrm{NO}_{2}{ }^{-}$to $\mathrm{NH}_{4}{ }^{+}$and $\mathrm{N}_{2} \mathrm{O}$ by a soil Citrobacter sp. Appl Environ Microbiol 43: $854-860$

Sørensen J (1978a) Capacity for denitrification and reduction of nitrate to ammonia in a coastal marine sediment. Appl Environ Microbiol 35:301-305

Sorensen J (1978b) Denitrification rates in marine sediments as measured by the acetylene inhibition technique. Appl Environ Microbiol 36:139-143

Sorensen J, Jørgensen BB, Revsbech NP (1979) A comparison of oxygen, nitrate, and sulfate respiration in coastal marine sediments. Microb Ecol 5:105-115

Souchu P, Gasc A, Cahet G, Vaquer A, Collos Y, Deslous-Paoli JM (1997) Biogeochemical composition of Mediterranean waters outside the Thau lagoon. Estuar Coast Shelf Sci (in press)

Szwerinski $\mathrm{H}$ (1981) Investigations on nitrification in the water and the sediment of the Kiel Bight (Baltic Sea). In: Rheinheimer G, Fluegel $\mathrm{H}$, Lenz J, Zeitzschel B (eds) Lower organisms and their role in the food web. Institut für Meereskunde, Kiel Meeresforsch 5:396-407

Thomas KL, Lloyd D (1995) Measurement of denitrification in estuarne sediment using membrane inlet mass spectrometry. FEMS Microbiol Ecol 16:103-114

Tiedje JM (1988) Ecology of denitrification and dissimilatory nitrate reduction to ammonium. In: Zehnder AJB (ed) Biology of anaerobic microorganisms. John Wiley and Sons Press, New York, p 179-244

Tiedje JM, Sextone AJ, Myrold DD, Robinson JA (1982) Denitrification: ecological niches, competition and survival. Antonie Leeuwenhoek 48:569-583

Tiedje JM, Sımkıns S, Groffman PM (1989) Perspective on measurement of denitrification in the field including recommended protocols for acetylene based methods. Plant Soil 115:261-284

Tournier H, Hamon PY, Landrein S (1982) Synthèse des observations réalisées par l'I.S.T.P.M sur les eaux et le plancton de Thau de 1974 à 1980. Rev Trav Inst Pêches Marit 45:283-318

Tréguer P, Le Corre P (1975) Manuel d'analyse des sels nutr1tifs dans l'eau de mer. Utilisation de l'auto analyseur II, Technicon. L.O.C. Univ Bretagne Occidentale, Brest

Visscher PT, Beukama J, van Gemerden H (1991) In situ characterisation of sediment: measurement of oxygen and sulfide profiles with a novel combined needle electrode. Limnol Oceanogr 36:1476-1480

Zeitzschel B (1980) Sediment-water interactions in nutrient dynamics. In: Tenore KR, Coull BC (eds) Marine benthic dynamics. University of South Carolina Press, Columbia, p $195-218$

Zimmerman AR, Benner R (1994) Denitrification, nutrient regeneration and carbon mineralization in sediments of Galveston Bay, Texas, USA. Mar Ecol Prog Ser 1 14:275-288

Manuscript first received: December 9, 1996

Revised version accepted: March 3, 1997 